Article

\title{
Lignin Syngas Bioconversion by Butyribacterium methylotrophicum: Advancing towards an Integrated Biorefinery
}

\author{
Marta Pacheco ${ }^{1,2}$ (D) Filomena Pinto ${ }^{1} \mathbb{D}$, Joana Ortigueira ${ }^{1,2}$, Carla Silva ${ }^{2, * \mathbb{D}}$, Francisco Gírio ${ }^{1}$ (D) \\ and Patrícia Moura $1, * \mathbb{D}$
}

1 LNEG, Laboratório Nacional de Energia e Geologia, Unidade de Bioenergia e Biorrefinarias, Estrada do Paço do Lumiar, 1649-038 Lisboa, Portugal; marta.pacheco@lneg.pt (M.P.); filomena.pinto@lneg.pt (F.P.); joana.ortigueira@lneg.pt (J.O.); francisco.girio@lneg.pt (F.G.)

2 Instituto Dom Luiz, Faculdade de Ciências, Universidade de Lisboa, 1749-016 Lisboa, Portugal

* Correspondence: camsilva@fc.ul.pt (C.S.); patricia.moura@lneg.pt (P.M.); Tel.: +351-210924600 (P.M.)

check for

updates

Citation: Pacheco, M.; Pinto, F.; Ortigueira, J.; Silva, C.; Gírio, F.;

Moura, P. Lignin Syngas

Bioconversion by

Butyribacterium methylotrophicum: Advancing towards an Integrated Biorefinery. Energies 2021, 14, 7124. https://doi.org/10.3390/

en14217124

Academic Editor: Byong-Hun Jeon

Received: 7 September 2021

Accepted: 20 October 2021

Published: 1 November 2021

Publisher's Note: MDPI stays neutral with regard to jurisdictional claims in published maps and institutional affiliations.

Copyright: (c) 2021 by the authors. Licensee MDPI, Basel, Switzerland. This article is an open access article distributed under the terms and conditions of the Creative Commons Attribution (CC BY) license (https:/ / creativecommons.org/licenses/by/ $4.0 /)$.

\begin{abstract}
Hybrid bio-thermochemical based technologies have the potential to ensure greater feedstock flexibility for the production of bioenergy and bioproducts. This study focused on the bioconversion of syngas produced from low grade technical lignin to $C_{2}-/ C_{4}$-carboxylic acids by Butyribacterium methylotrophicum. The effects of $\mathrm{pH}$, medium supplementation and the use of crude syngas were analyzed. At $\mathrm{pH}$ 6.0, B. methylotrophicum consumed $\mathrm{CO}, \mathrm{CO}_{2}$ and $\mathrm{H}_{2}$ simultaneously up to $87 \mathrm{~mol} \%$ of carbon fixation, and the supplementation of the medium with acetate increased the production of butyrate by 6.3 times. In long-term bioreactor experiments, B. methylotrophicum produced 38.3 and $51.1 \mathrm{mM}$ acetic acid and 0.7 and $2.0 \mathrm{mM}$ butyric acid from synthetic and lignin syngas, respectively. Carbon fixation reached 83 and $88 \mathrm{~mol} \%$, respectively. The lignin syngas conversion rate decreased from 13.3 to $0.9 \mathrm{NmL} / \mathrm{h}$ throughout the assay. The appearance of a grayish pellet and cell aggregates after approximately $220 \mathrm{~h}$ was indicative of tar deposition. Nevertheless, the stressed cells remained metabolically active and maintained acetate and butyrate production from lignin syngas. The challenge that impurities represent in the bioconversion of crude syngas has a direct impact on syngas cleaning requirements and operation costs, supporting the pursuit for more robust and versatile acetogens.
\end{abstract}

Keywords: carboxydotrophic; acetogenic bacteria; carbon fixation; crude syngas; acetic acid; butyric acid; bio-thermochemical-based lignocellulosic biorefineries

\section{Introduction}

Concerns regarding the depletion of finite feedstock resources have shifted industrial sectors to the use of renewable biomass and the adoption of circular business models. In 2020, the bio-based industry in Europe was represented by 2362 facilities, from which 788 integrated the production of bioproducts and energy, including biofuels and other types of energy from biomass [1]. Although biomass plants tend to be efficient at its conversion, there are still waste streams generated from this process. Low-grade technical lignin from lignocellulosic biomass is one of such examples. Its polymeric composition and high stability make it impervious to enzymatic hydrolysis and other biological decomposition processes [2]. Due to its recalcitrant properties and high heating value, lignin has become a preferred feedstock for thermochemical plants, particularly for gasification [3].

The main product of gasification is synthesis gas or syngas, which is mainly composed of carbon monoxide $(\mathrm{CO})$, hydrogen $\left(\mathrm{H}_{2}\right)$, carbon dioxide $\left(\mathrm{CO}_{2}\right)$, and also, in lower amounts, of methane $\left(\mathrm{CH}_{4}\right)$, short chain hydrocarbons $\left(\mathrm{C}_{\mathrm{n}} \mathrm{H}_{\mathrm{n}}\right)$, ammonia $\left(\mathrm{NH}_{3}\right)$ and hydrogen sulfide $\left(\mathrm{H}_{2} \mathrm{~S}\right)[3,4]$. Syngas is a versatile feedstock for the production of fuels and chemicals, and some microorganisms can use the main syngas components as a source of carbon and energy. Some species of bacteria and archaea, known as carboxydotrophs, can produce a variety of short chain organic acids and alcohols from syngas [5,6]. Although syngas 
fermentation is not a recent technology, over the years, knowledge in this field has been focused on the use of synthetic syngas formulations. Synthetic syngas is a custom-made gaseous mixture of $\mathrm{CO}, \mathrm{H}_{2}, \mathrm{CO}_{2}$ and $\mathrm{N}_{2}$ in various ratios. Such mixtures are perfect for fermentation parameter optimization and fundamental research because they allow for a flexibility that crude syngas cannot offer, as they are independent of feedstock and gasification conditions [7]. However, the composition of crude syngas is highly complex, and not exclusive to the main gaseous components. Contaminants such as tar, cyanide and other molecules are recognized as one of the biggest obstacles for direct syngas fermentation. These molecules can be present in concentrations shown to hinder microbial growth, significantly affecting overall yields and productivities [6-14]. For example, the presence of tar in crude syngas produced by lignin gasification was shown to induce cell dormancy and influence the redistribution of ethanol and acetic acid production by Clostridium carboxidivorans $\mathrm{P}^{\mathrm{T}}$ and Clostridium ragsdalei $\mathrm{P} 11[15,16]$. Fortunately, some of these inhibitory effects may be mitigated by gradually adapting microbial cultures to crude syngas, prior to fermentation $[9,10,17]$.

Butyribacterium methylotrophicum is a mesophilic carboxydotrophic acetogen, which is able to produce a variety of organic acids and alcohols from syngas. B. methylotrophicum was isolated from a sewage sludge digestor in 1980 by Zeikus et al. [18] and is described as being able to grow from a multitude of carbon sources, including carbon gaseous mixtures. This microorganism uses the Wood-Ljungdahl (WL) acetyl-CoA formation pathway to convert $\mathrm{CO}$ and $\mathrm{CO}_{2}+\mathrm{H}_{2}$ to biomass and metabolites (acetate, butyrate, ethanol and butanol) $[19,20]$. Acetate and butyrate can be further used as platform chemicals for varied applications including food, pharmaceutical and chemical products, replacing processes based on chemical conversion at high temperatures and pressures. Ethanol and butanol are also important as precursors for next generation biofuels [21-23]. The fermentative production of such compounds could contribute to a more environmentally friendly economy, less dependent on fossil fuels [24].

Although B. methylotrophicum is a promising microorganism for syngas-to-bioproducts processes, research on the fermentation process has been only carried out with synthetic syngas mixtures. The current challenges of syngas bioconversion are mostly associated with the search for new and robust biocatalysts, low biomass yields, mass transfer limitations, and aspects of process integration and intensification [6,25]. Microbial catalysts must be stable enough to withstand a prolonged conversion fed by real gases, in processes that may represent a huge potential for future applications; for example, the carbon fixation of $\mathrm{CO}_{2}$-rich flue gas streams. More robust acetogenic microorganisms are required, such as those that are being developed by Arantes et al., 2021 and Diender et al., 2021, to tackle the conversion of syngas to platform molecules and tolerate a greater variety of syngas compositions [26,27]. Studies that integrate gasification and crude syngas fermentation, based on the development of scalable bioreactor configurations, with efficient material flow integration and that address the problem of microbial resistance to crude syngas impurities are also still scarce $[8,9,28]$. A complete scale-up and techno-economic assessment are also necessary to substantiate the integration of the biochemical and thermochemical platforms, as they are essential for the full application of this hybrid technology in carbon fixation processes [29].

This work focused on testing the conditions to maximize $C_{2}$ - and $C_{4}$-carboxylic acids production by $B$. methylotrophicum, first from a synthetic syngas mixture mimicking lignin syngas, and then from crude syngas obtained by the gasification of low-grade technical lignin generated as a by-product in a second-generation (2G) ethanol biorefinery. Two different types of syngas feeding modes were tested-batch and on-demand feedingallowing for a comprehensive analysis of the behavior of this microorganism under more adverse fermentative conditions. 


\section{Materials and Methods}

\subsection{Microorganism, Culture Media and Syngas Composition}

The microbial strain used in this study was Butyribacterium methylotrophicum strain Marburg DSM 3468 (Deutsche Sammlung von Mikroorganismen und Zellkulturen, Braunschweig, Germany). The culture medium was adapted from Oswald et al., 2016 and was composed of $2 \mathrm{~g} / \mathrm{L} \mathrm{NaCl}, 2.5 \mathrm{~g} / \mathrm{L} \mathrm{NH}_{4} \mathrm{Cl}, 0.25 \mathrm{~g} / \mathrm{L} \mathrm{KCl}, 0.25 \mathrm{~g} / \mathrm{L} \mathrm{KH}_{2} \mathrm{PO}_{4}, 0.5 \mathrm{~g} / \mathrm{L}$ $\mathrm{MgSO}_{4} \cdot 7 \mathrm{H}_{2} \mathrm{O}, 0.1 \mathrm{~g} / \mathrm{L} \mathrm{CaCl} 2 \cdot 2 \mathrm{H}_{2} \mathrm{O}, 0.001 \mathrm{~g} / \mathrm{L}$ resazurin, $0.56 \mathrm{~g} / \mathrm{L}$ cysteine- $\mathrm{HCl} \cdot \mathrm{H}_{2} \mathrm{O}$, $2 \mathrm{~g} / \mathrm{L}$ yeast extract and $10 \mathrm{~mL} / \mathrm{L}$ trace elements solution (see below) [28]. A concentration of $140 \mathrm{mM}$ phosphate buffer or $20 \mathrm{~g} / \mathrm{L} 2$-( $n$-morpholino)ethanesulfonic acid (MES) was used in the culture medium formulation at $\mathrm{pH} 7.0$ and $\mathrm{pH} 6.0$, respectively. The medium was first made anoxic by replacing the gas phase by nitrogen $\left(\mathrm{N}_{2}\right)$ through a gas manifold system. Afterwards, the serum bottles were sparged with synthetic syngas (Syngas A-Table 1) for $10 \mathrm{~min}$. After autoclaving, $10 \mathrm{~mL} / \mathrm{L}$ of vitamin solution and, optionally, $60 \mathrm{mM}$ of sodium acetate were aseptically added. The trace elements solution contained: $2.0 \mathrm{~g} / \mathrm{L}$ sodium ethilenediaminetetracetic acid (EDTA), $1.0 \mathrm{~g} / \mathrm{L} \mathrm{MnSO}{ }_{4} \cdot \mathrm{H}_{2} \mathrm{O}, 0.567 \mathrm{~g} / \mathrm{L} \mathrm{FeSO}_{4} \cdot 7 \mathrm{H}_{2} \mathrm{O}, 0.022 \mathrm{~g} / \mathrm{L} \mathrm{Na}_{2} \mathrm{WO}_{4} \cdot 2 \mathrm{H}_{2} \mathrm{O}, 0.2 \mathrm{~g} / \mathrm{L} \mathrm{CoCl} 2 \cdot 6 \mathrm{H}_{2} \mathrm{O}$, $0.2 \mathrm{~g} / \mathrm{L} \mathrm{ZnSO} \cdot 7 \mathrm{H}_{2} \mathrm{O}, 0.02 \mathrm{~g} / \mathrm{L} \mathrm{CuCl}_{2} \cdot 2 \mathrm{H}_{2} \mathrm{O}, 0.02 \mathrm{~g} / \mathrm{L} \mathrm{NiCl}_{2} \cdot 6 \mathrm{H}_{2} \mathrm{O}, 0.02 \mathrm{~g} / \mathrm{L} \mathrm{Na}_{2} \mathrm{MoO}_{4} \cdot 2 \mathrm{H}_{2} \mathrm{O}$ and $0.02 \mathrm{~g} / \mathrm{L} \mathrm{Na}_{2} \mathrm{SeO}_{3} \cdot 5 \mathrm{H}_{2} \mathrm{O}$. The filter sterilized vitamin solution contained: $0.01 \mathrm{~g} / \mathrm{L}$ pyridoxine, $0.005 \mathrm{~g} / \mathrm{L}$ calcium pantothenate, $0.005 \mathrm{~g} / \mathrm{L}$ nicotinic acid, $0.005 \mathrm{~g} / \mathrm{L}$ riboflavin, $0.005 \mathrm{~g} / \mathrm{L}$ thiamine $\cdot \mathrm{HCl}, 0.005 \mathrm{~g} / \mathrm{L}$ thioctic acid, $0.005 \mathrm{~g} / \mathrm{L}$ vitamin B12, $0.002 \mathrm{~g} / \mathrm{L}$ biotin and $0.002 \mathrm{~g} / \mathrm{L}$ folic acid. The culture medium for the maintenance of syngas adapted cells was inoculated at $2 \%(v / v)$ every 4 days and incubated at $37^{\circ} \mathrm{C}, 150 \mathrm{rpm}$ in an orbital shaker $[7,18]$.

Table 1. Composition of the syngas used for bioconversion by B. methylotrophicum. Syngas A was the synthetic syngas formulation and Syngas B was obtained from the gasification of technical lignin.

\begin{tabular}{cccc}
\hline Syngas Compound & Syngas A & Syngas $\mathbf{B}^{+}$ & Units \\
\hline $\mathrm{CO}$ & 30.0 & 24.2 & $\mathrm{vol} \%$ \\
$\mathrm{CO}_{2}$ & 20.0 & 16.5 & $\mathrm{vol} \%$ \\
$\mathrm{H}_{2}$ & 30.0 & 23.9 & $\mathrm{vol} \%$ \\
$\mathrm{CH}_{4}$ & - & 13.6 & $\mathrm{vol} \%$ \\
$\mathrm{~N}_{2}$ & 20.0 & 18.1 & $\mathrm{vol} \%$ \\
$\mathrm{O}_{2}$ & - & 0.4 & $\mathrm{vol} \%$ \\
$\mathrm{C}_{2} \mathrm{H}_{2}$ & - & $\mathrm{nd} \ddagger$ & - \\
$\mathrm{C}_{2} \mathrm{H}_{4}$ & - & 3.0 & $\mathrm{vol} \%$ \\
$\mathrm{C}_{2} \mathrm{H}_{6}$ & - & 0.1 & $\mathrm{vol} \%$ \\
$\mathrm{C}_{3} \mathrm{H}_{6}$ & - & 300 & $\mathrm{ppmV}$ \\
$\mathrm{C}_{3} \mathrm{H}_{8}$ & - & 500 & $\mathrm{ppmV}$ \\
$\mathrm{C}_{4} \mathrm{H}_{10}$ & - & 300 & $\mathrm{ppmV}$ \\
$\mathrm{NH}_{3}$ & - & 760 & $\mathrm{ppmV}$ \\
$\mathrm{H}_{2} \mathrm{~S}$ & - & 180 & $\mathrm{ppmV}$ \\
\hline
\end{tabular}

${ }^{\dagger}$, Values are at standard conditions of temperature and pressure-temperature of $25^{\circ} \mathrm{C}(293.15 \mathrm{~K})$ and absolute pressure of $1.0 \times 10^{5} \mathrm{~Pa} . \ddagger$, not detected

The culture media formulation in the bioreactor assays was the same as described above except for the buffer solution: $20 \mathrm{~g} / \mathrm{L}$ MES sodium salt at both $\mathrm{pH}$ values tested. A $2 \mathrm{M} \mathrm{NaOH}$ solution was used to maintain the $\mathrm{pH}$, and $10 \mathrm{M} \mathrm{H}_{2} \mathrm{SO}_{4}$ solution was used to lower the $\mathrm{pH}$ in the bioreactor to 6.0, when needed. The culture medium in the bioreactor was inoculated with $8 \%(v / v)$ B. methylotrophicum pre-cultured at $37{ }^{\circ} \mathrm{C}, 150 \mathrm{rpm}$ for $48 \mathrm{~h}$.

In this study, two syngas compositions were used: a synthetic composition of syngas (Syngas A) and lignin-derived syngas (Syngas B). Table 1 shows the concentrations of the main syngas compounds. Syngas B was obtained through the gasification of technical lignin (lignin A sample) obtained from a 2G biorefinery plant, in a bench-scale bubbling fluidized bed gasifier (BFB) with a height of $1.5 \mathrm{~m}$ and an interior diameter of $0.08 \mathrm{~m}$. Details about lignin composition and gasification conditions are described elsewhere [3]. 
The gasifier was operated at $850{ }^{\circ} \mathrm{C}$ and atmospheric pressure. The lignin flow rate was around $5 \mathrm{~g}$ daf/min (dry and ash free). The lignin/steam ratio was about 1 and the equivalent ratio (ER) was around 0.2. The gasifying/fluidizing agent was a mixture of steam and oxygen, introduced through a gas distributor located at the base of the gasifier. The produced syngas was passed through a cyclone and was cooled down, in order to remove particulates and condensates. Finally, the gas was filtered before being collected to be used in the fermentation assays. The formulation of synthetic Syngas A with a ratio of $\mathrm{CO} / \mathrm{H}_{2}=1.0$ was adapted from Oswald et al., 2016 [28].

\subsection{Experimental Set-Up}

In the small-scale bioconversion assays, B. methylotrophicum was cultured anaerobically in $120 \mathrm{~mL}$ serum flasks with $20 \mathrm{~mL}$ of culture medium, at $37^{\circ} \mathrm{C}$ and $150 \mathrm{rpm}$. To increase mass transfer and facilitate gas consumption, flasks were placed horizontally in the incubator. At each sampling time three flasks were withdrawn for processing.

In the batch bioreactor experiments, B. methylotrophicum was cultured in a $1.65 \mathrm{~L}$ air-tight double jacketed glass vessel with $500 \mathrm{~mL}$ working volume. The reactor was equipped with a pH sensor (405-DPAS-SC-K8S/250, Mettler Toledo, OH, USA) and controller (Black Stone BL 931700 pH controller, Hanna Instruments, Johannesbourg, South Africa), and all the necessary inlets/outlets for $\mathrm{pH}$ control, gas sampling, pressure measurement (LabQuest2 with gas pressure sensor, Vernier, OR, USA), syngas feed, liquid sampling/inoculum addition and syngas outlet. Temperature and stirring were $37^{\circ} \mathrm{C}$ and $400 \mathrm{rpm}$, respectively. Two different $\mathrm{pH}$ values were set in this experiment. In the first phase the $\mathrm{pH}$ was maintained at 7.0, for biomass and acetate accumulation. In the second phase the $\mathrm{pH}$ was lowered to 6.0, to promote butyrate production [30].

Two different syngas feeding modes were tested in the bioreactor experiments. The first consisted of aerating the bioreactor headspace with synthetic syngas until saturation. Carbon conversion occurred solely at the expense of the syngas present in the bioreactor headspace. Syngas consumption was monitored by the decrease of pressure inside the reactor, after which the headspace was batch-refilled with new syngas. The second syngas feeding mode consisted in connecting a $\mathrm{H}_{2}$ tight gas sampling bag (SKC 263-03 Standard FlexFoil ${ }^{\circledR}$ series with stainless steel fittings, PA, USA) filled with the respective syngas mixture. The syngas entrance in the bioreactor occurred when the pressure inside the glass vessel was sufficiently low to pull the gas from the bag. The syngas influx was measured through an inline flow meter ( $\mu$ flow, Bioprocess Control, Stockholm, Sweden) connected to the gas sampling bag. The nutrients were replaced by fresh autoclaved concentrated culture medium at the end of each batch.

\subsection{Analytical Methods}

The microbial growth was monitored by optical density at $600 \mathrm{~nm}$ (Thermo Fisher Scientific spectrophotometer, Genesys 20, MA, USA) and the cell dry weight (CDW) was quantified according to official methods of analysis [31]. Acetic and butyric acids were quantified by High-Performance Liquid Chromatography (HPLC) with a Biorad Aminex HPX-87H column (Bio-Rad Laboratories, CA, USA) at $35^{\circ} \mathrm{C}$, in a LaChrom L-7490 (Merck, Darmstadt, Germany) chromatographer equipped with a differential refractive index detector. The liquid phase used was $0.5 \mathrm{mM} \mathrm{H}_{2} \mathrm{SO}_{4}$, at a flow rate of $0.4 \mathrm{~mL} / \mathrm{min}$. Solutions of the carboxylic acids were used as external standards. Gas samples were analyzed through gas chromatography (GC) in an Agilent/HP 6890 gas chromatograph equipped with a gas sampling valve, two filling columns (Molecular Sieve 5A and Porapak Q) and two detectors (Thermal Conductivity Detector and Flame Ionization Detector) mounted in series. Each injected sample was heated to $40^{\circ} \mathrm{C}$ for $17 \mathrm{~min}$ and then up to $185^{\circ} \mathrm{C}$ for $43 \mathrm{~min}$, with a heating rate of $15^{\circ} \mathrm{C} / \mathrm{min}$. The carrier gas used was argon at a constant flow of $18.5 \mathrm{~mL} / \mathrm{min}$. The molar concentration of $\mathrm{CO}, \mathrm{H}_{2}$ and $\mathrm{CO}_{2}$ were estimated from the GC analysis using the Peng-Robinson equation [32]. 


\subsection{Calculations}

In the assays where the culture medium was supplemented with sodium acetate, the acetate production was determined as the difference between the concentration in the samples collected from the supplemented culture medium at each time-point and the concentration determined immediately after the supplementation occurred.

The amount of $\mathrm{CO}$ and $\mathrm{CO}_{2}$, in mol, that was used by the cells to form products and to be incorporated as biomass per mol of $\mathrm{CO}$ and $\mathrm{CO}_{2}$ fed was referred to as carbon fixation $(\mathrm{CF})$, and was estimated as follows:

$$
\text { Carbon fixation }(\%)=\frac{\mathrm{n}\left(\mathrm{CO}+\mathrm{CO}_{2}\right)_{\mathrm{i}}-\mathrm{n}\left(\mathrm{CO}+\mathrm{CO}_{2}\right)_{\mathrm{f}}}{\mathrm{n}\left(\mathrm{CO}+\mathrm{CO}_{2}\right)_{\mathrm{i}}} \times 100
$$

where $\mathrm{n}\left(\mathrm{CO}+\mathrm{CO}_{2}\right)$ corresponds to the sum of the number of moles of $\mathrm{CO}$ and $\mathrm{CO}_{2}$ in the headspace of the bioreactor or the serum flask, and $i$ and $f$ correspond to the initial and final batch period. This equation was adapted from the carbon fixation equations used by Infantes et al., 2020 [33].

\section{Results and Discussion}

\subsection{Effect of Varying $p H$ and Medium Supplementation on Syngas Bioconversion by} B. methylotrophicum

As a preliminary evaluation of B. methylotrophicum fermentative behavior, an initial assay was performed in serum flasks using Syngas A as carbon and energy source. Based on data from the literature [30], two initial $\mathrm{pH}$ values were tested, 7.0 and 6.0. To evaluate the effect on butyrate production, the supplementation of the culture broth at $\mathrm{pH} 6.0$ with $60 \mathrm{mM}$ sodium acetate was also tested.

Figure 1 and Table 2 show the results obtained.

Cellular growth, organic acids production, and $\mathrm{CO}, \mathrm{CO}_{2}$ and $\mathrm{H}_{2}$ fixation were observed under all the tested conditions. According to the $\mathrm{CO}, \mathrm{CO}_{2}$ and $\mathrm{H}_{2}$ fixation profiles, it was observed that $\mathrm{CO}$ was the preferred carbon and energy source under all the tested conditions, since it was consumed at a faster rate than $\mathrm{H}_{2}+\mathrm{CO}_{2}$. The concentration of $\mathrm{CO}_{2}$ results from a balance between uptake and production by the WL pathway. Because $\mathrm{CO}_{2}$ can be used as a carbon source, but needs the presence of $\mathrm{H}_{2}$ as energy source, $\mathrm{H}_{2}$ consumption was considered to be an indicator of $\mathrm{CO}_{2}$ uptake by the cells [34].

Table 2. Growth rate, acetate and butyrate production, $\mathrm{pH}$ and pressure decrease achieved in the culture of $B$. methylotrophicum with Syngas A, at $\mathrm{pH} 7.0$ and $\mathrm{pH}$ 6.0, with or without medium supplementation of the culture medium with sodium acetate.

\begin{tabular}{cccc}
\hline Parameter & pH 7.0 & pH 6.0 & pH 6.0 and NaAc \\
\hline Max. specific growth rate ${ }^{2}\left(\mathrm{~h}^{-1}\right)$ & $0.07\left(\mathrm{R}^{2}=0.99\right)$ & $0.05\left(\mathrm{R}^{2}=1.00\right)$ & $0.05\left(\mathrm{R}^{2}=0.97\right)$ \\
Acetate $(\mathrm{mM})$ & $29.0 \pm 1.0$ & $32.0 \pm 1.2$ & $20.2 \pm 0.3$ \\
Butyrate $(\mathrm{mM})$ & $1.7 \pm 0.4$ & $0.9 \pm 0.1$ & $5.7 \pm 0.1$ \\
Butyrate/acetate produced $(\mathrm{mol} / \mathrm{mol})$ & 0.06 & 0.05 & 0.59 \\
Final pH & $6.6 \pm 0.1$ & $5.8 \pm 0.0$ & $6.0 \pm 0.0$ \\
Pressure after 120 $\mathrm{h}(\mathrm{kPa})^{3}$ & 42.6 & 44.6 & 45.6 \\
CF (mol \%) & 61 & 87 & 86 \\
\hline
\end{tabular}

${ }^{1}$, NaAc, sodium acetate; ${ }^{2}$, Based on $\ln$ O.D.600nm $;{ }^{3}$, Pressure value measured inside the serum flasks; CF, Carbon fixation determined using Equation (1), from $0-120 \mathrm{~h}$. 
a)

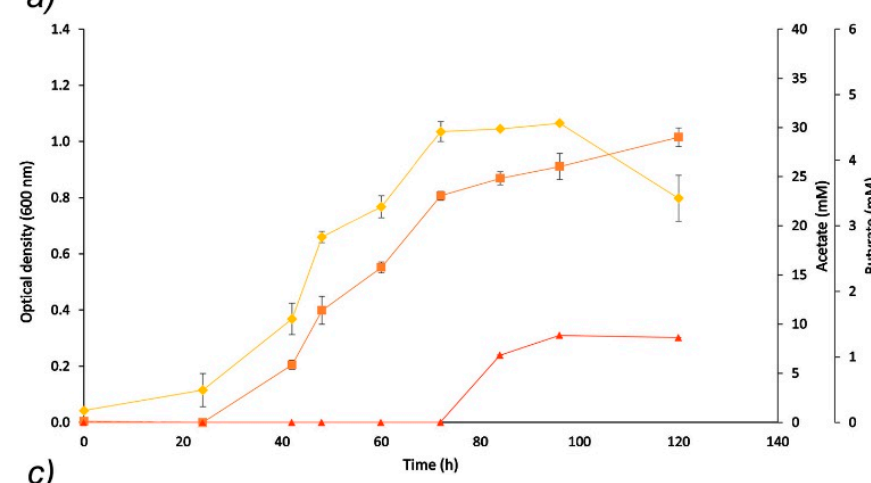

c)

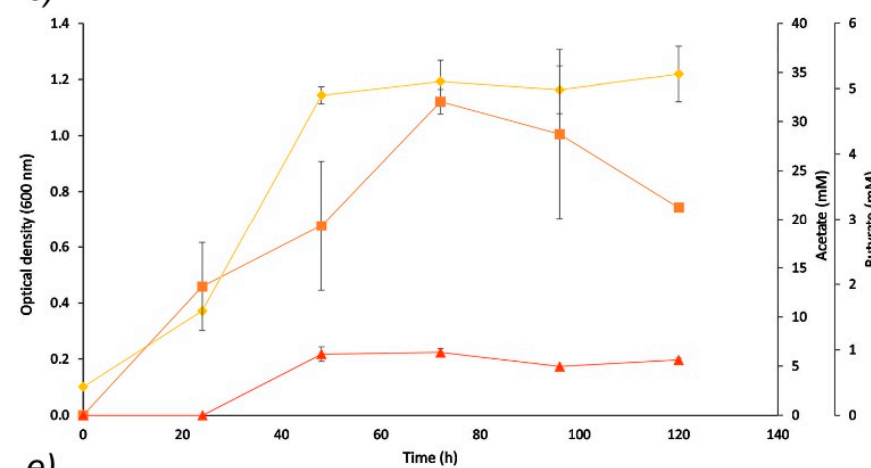

e)

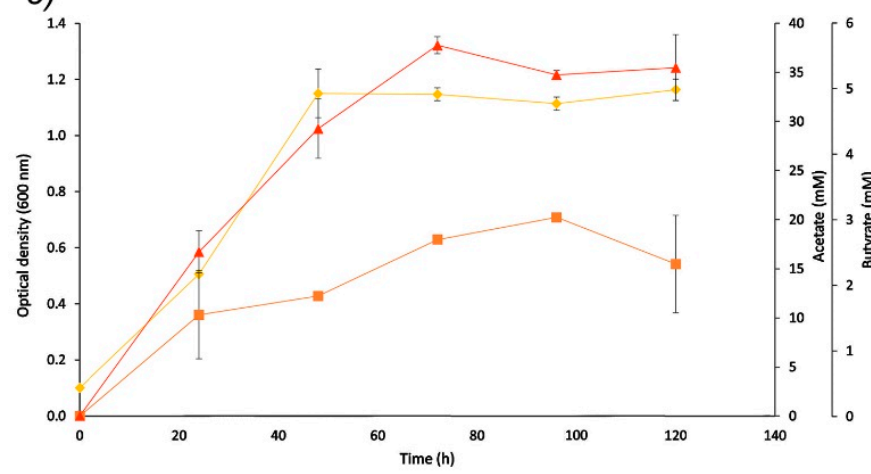

b)

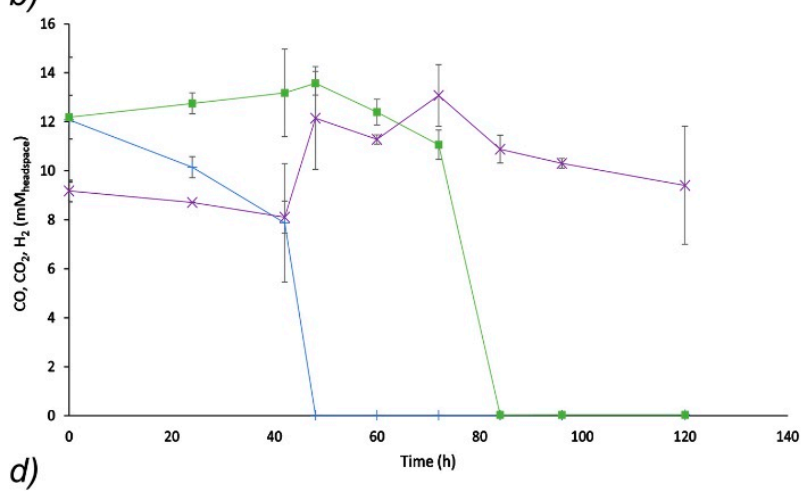

d)

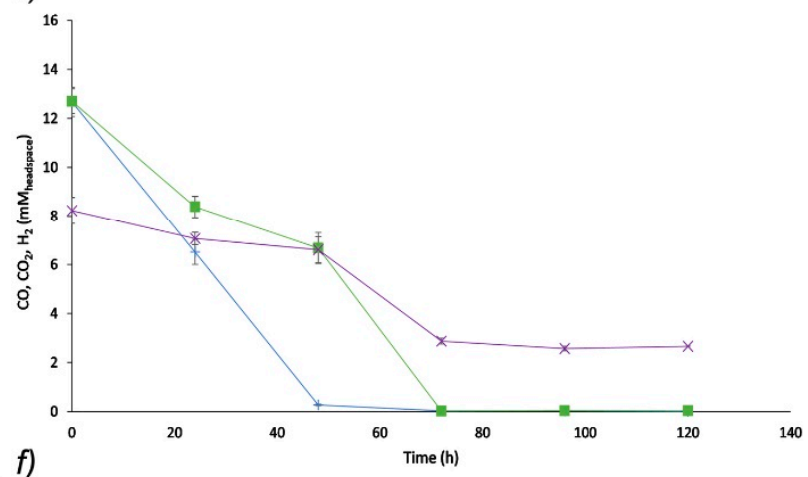

f)

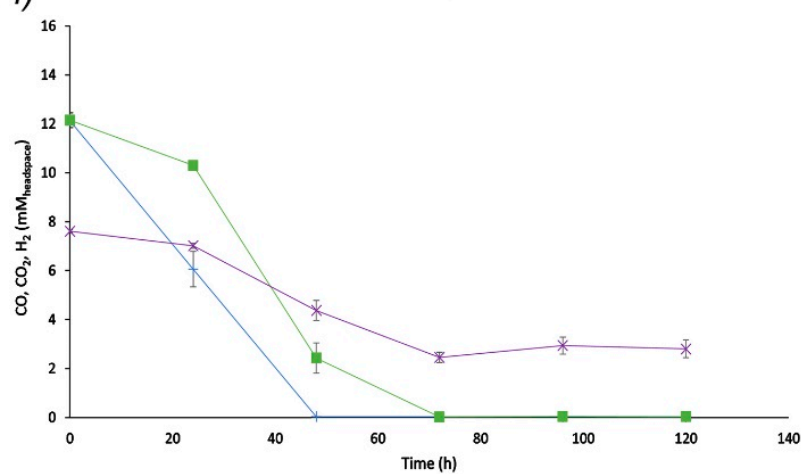

Figure 1. Cell growth, acetate and butyrate production, and $\mathrm{CO}, \mathrm{CO}_{2}$ and $\mathrm{H}_{2}$ fixation by B. methylotrophicum cultured with Syngas A in serum flasks at: pH $7.0(\mathbf{a}, \mathbf{b}) ; \mathrm{pH} 6.0(\mathbf{c}, \mathbf{d})$; and $\mathrm{pH} 6.0$ with supplementation of sodium acetate (e,f). The results are average values of two experiments. Standard deviation was performed with 3 experimental repetitions. $(-\cdots \mathrm{Optical}$ density at $600 \mathrm{~nm} ;--$ acetate; - butyrate; $\left.--\mathrm{CO} ;---\mathrm{H}_{2} ;-\leftarrow-\mathrm{CO}_{2}\right)$.

At $\mathrm{pH} 7.0$ the production of acetate started at the beginning of the exponential growth phase (Figure 1a). The onset of butyrate production occurred only during the stationary growth phase $(72-84 \mathrm{~h})$, when the $\mathrm{pH}$ of the medium decreased to 6.6 and the concentration of acetate in the medium amounted to 23.1-24.8 mM. Carbon monoxide was depleted from the headspace at a consumption rate of $0.25 \mathrm{mM} / \mathrm{h}$ up to $48 \mathrm{~h}$ (Figure $1 \mathrm{~b}$ ). The $\mathrm{H}_{2}$ fixation profile showed no decrease until $\mathrm{CO}$ depletion, after which it was totally consumed during the $48-84 \mathrm{~h}$ period, at a rate of $0.36 \mathrm{mM} / \mathrm{h}$. This preference for $\mathrm{CO}$ consumption by $B$. methylotrophicum was also observed by Heiskanen et al., 2007 at pH 7.3 [35]. The CO acted as a hydrogenase inhibitor, which caused a delay in $\mathrm{H}_{2}$ consumption. The $\mathrm{CO}_{2}$ concentration oscillated between production and consumption over the $120 \mathrm{~h}$ of fermentation, at $\mathrm{pH}$ 7.0.

At $\mathrm{pH}$ 6.0, acetate was immediately detected after inoculation, and butyrate production started approximately in the mid exponential growth phase after $24 \mathrm{~h}$ (Figure $1 \mathrm{c}$ ). The supplementation of the culture medium with $60 \mathrm{mM}$ of sodium acetate did not inhibit syngas conversion by B. methylotrophicum. However, a drastic change in both acetate and butyrate production was observed. Not only did the maximum acetate production 
decrease from 32.0 to $20.2 \mathrm{mM}$, but also the butyrate production increased 6.3 times, up to $5.7 \mathrm{mM}$. Figure 1e shows that both acetate and butyrate production started with the exponential growth phase. At pH 6.0, carbon uptake was faster than at $\mathrm{pH} 7.0$, and the $\mathrm{CO}$ and $\mathrm{H}_{2}$ fixation profiles were similar either with or without acetate supplementation. The concentrations of $\mathrm{CO}$ and $\mathrm{H}_{2}$ decreased simultaneously after the inoculation of the culture medium until depletion at 48 and $72 \mathrm{~h}$, respectively (Figure 1d,f). The consumption rates of $\mathrm{CO}$ and $\mathrm{H}_{2}$ were similar with or without acetate supplementation, respectively $0.25-0.26 \mathrm{mM} / \mathrm{h}$ for $\mathrm{CO}$ and $0.17-0.18 \mathrm{mM} / \mathrm{h}$ for $\mathrm{H}_{2}$. The $\mathrm{CO}_{2}$ balance at $\mathrm{pH} 6.0$, with or without acetate supplementation, resulted in a net decrease of 4.8 and $5.6 \mathrm{mM}$, respectively. Carbon fixation was higher at pH 6.0 (Table 2), indicating that carbon was being used for anabolic and catabolic purposes rather than being released as $\mathrm{CO}_{2}$. Nevertheless, the concentration of $\mathrm{H}_{2}$ present in the Syngas A formulation was not sufficient to assure $\mathrm{CO}_{2}$ depletion (Figure $1 \mathrm{~d}, \mathrm{f}$ ). Theoretically, an additional 1.6-fold increase in $\mathrm{H}_{2}$ would be required to fully consume the supplied carbon.

The culture of $B$. methylotrophicum at $\mathrm{pH} 6.0$ with sodium acetate supplementation yielded the best results of $C_{2}$ and $C_{4}$ acid production, and carbon fixation (Table 2). However, the profiles of acetate and butyrate varied in the three conditions tested. Butyrate is described in the literature as a secondary metabolite that starts to be produced by acetogens such as B. methylotrophicum and Eubacterium limosum during the stationary growth phase $[29,35,36]$. In this study, this was observed for $\mathrm{pH} 7.0$; however, at $\mathrm{pH} 6.0$ butyrate was produced during the exponential growth phase. When the culture medium was supplemented with sodium acetate, butyrate production started simultaneously with acetate production, immediately after inoculation. Without supplementation, the main product of Syngas A bioconversion was acetate, and the production of butyrate was residual. The low $\mathrm{pH}$ together with excess acetate shifted B. methylotrophicum metabolism to more reduced products (Table 2). This effect was described by Worden et al., 1989, where a sudden $\mathrm{pH}$ reduction from $\mathrm{pH} 6.8$ to 6.0 after $72 \mathrm{~h}$ of $B$. methylotrophicum growth incremented butyrate production from CO by approximately 23 times [30]. Diender et al., 2016 also observed that the external addition of acetate to a co-culture of Clostridium autoethanogenum and Clostridium kluyveri increased butyrate production approximately 7 times [30,37]. This metabolic shift may be related to an acidity protection mechanism. A high concentration of protons in solution disrupts membrane potential, affecting cellular metabolism and increasing acetate toxicity towards microbial cells [38-41]. Furthermore, as described by Grethlein et al., 1990, B. methylotrophicum growth was greatly affected by $\mathrm{pH}$ lower than 6.0. At $\mathrm{pH} 5.5$, biomass was half that obtained at $\mathrm{pH} 6.0$, whereas $\mathrm{pH} 5.0$ resulted in cell washout [42]. The preference for reduced products at low $\mathrm{pH}$ also has an effect in the ATP balance of the cell. The acetate pathway is the preferred ATP source, however, under high acetate concentrations, either acetate kinase or phosphotransacetylase become inhibited, and the carbon influx is diverted into the butyrate pathway to compensate the energy loss $[43,44]$.

\subsection{Long-Term Synthetic Syngas Bioconversion by B. methylotrophicum}

The bioreactor set-up to test the long-term syngas bioconversion by B. methylotrophicum at different $\mathrm{pH}$ values was processed in two sequential stages: in the first stage the $\mathrm{pH}$ of the culture medium was adjusted to 7.0 in order to maximize the acetate concentration; the second stage started with the $\mathrm{pH}$ adjustment to 6.0, to induce butyrate production. The complete Syngas A fermentation assay comprised a total of $483 \mathrm{~h}$ : the first $288 \mathrm{~h}$ at $\mathrm{pH} 7.0$ and from 288 to $483 \mathrm{~h}$ at pH 6.0 (Figure 2). Table 3 shows the main bioconversion outcomes. 


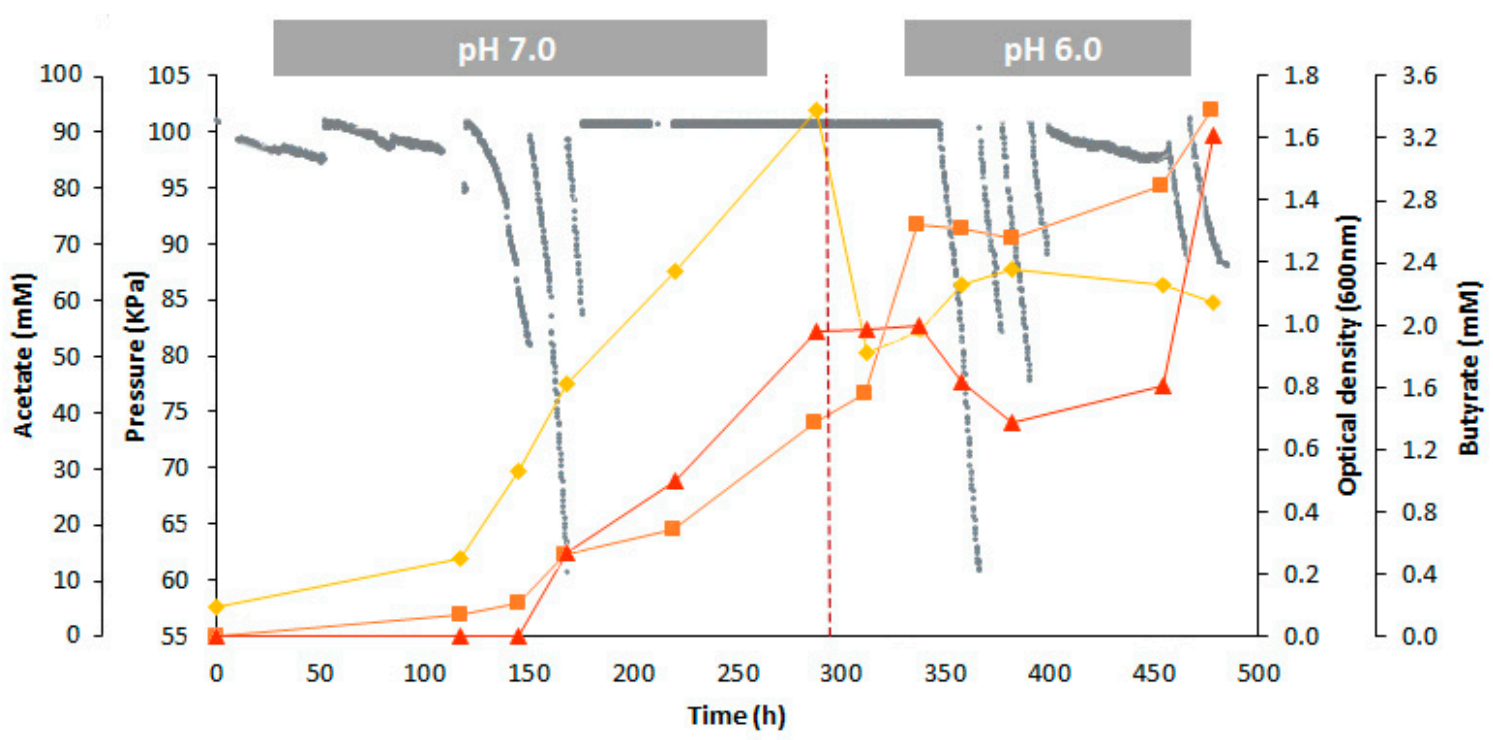

Figure 2. Time course representation of pressure variation, cell density, acetate and butyrate production by B. methylotrophicum cultured with Syngas A in bioreactor at pH 7.0 and pH 6.0 (- - pressure inside the bioreactor; -- Optical density at $600 \mathrm{~nm} ;--$ - acetate; - - butyrate; $-\mathrm{pH}$ set-point change).

Table 3. Growth, acetate and butyrate production, and minimum pressure achieved in the bioconversion of Syngas A by B. methylotrophicum at pH 7.0 (0-288 h) and pH 6.0 (288-483 h).

\begin{tabular}{|c|c|c|}
\hline Parameters. & pH 7.0 & pH 6.0 \\
\hline Max. specific growth rate ${ }^{1}\left(h^{-1}\right)$ & 0.012 & 0.006 \\
\hline Acetate $(\mathrm{mM})^{2}$ & 38.3 & 20.2 \\
\hline Butyrate $(\mathrm{mM})^{2}$ & 2.0 & 1.2 \\
\hline Butyrate/Acetate produced $(\mathrm{mol} / \mathrm{mol})$ & 0.05 & 0.16 \\
\hline Min. pressure ${ }^{3}(\mathrm{kPa})$ & 60.8 & 60.9 \\
\hline $\mathrm{CF}(\mathrm{mol} \%)$ & 83 & 79 \\
\hline
\end{tabular}

1 , Based on $\ln ($ O.D.600nm $) ;{ }^{2}$, Production was estimated as the concentration increase during the operation at each $\mathrm{pH}$ value; ${ }^{3}$, Minimum pressure value measured inside the bioreactor headspace; $\mathrm{CF}$, Carbon fixation determined, using Equation (1), from 175 to $287 \mathrm{~h}$ (during on-demand syngas feeding) for $\mathrm{pH} 7.0$ and 465 to $483 \mathrm{~h}$ (during batch syngas feeding) for $\mathrm{pH} 6.0$.

Syngas A infeed to the bioreactor was performed in two supply modes: (I) the syngas was supplied in sequential batches, until the pressure value inside the bioreactor decreased to approximately $60.8 \mathrm{kPa}$ and where the rate of syngas consumption was measured as the rate of pressure decrease inside the bioreactor; or (II) the syngas was supplied on-demand, where the pressure inside the bioreactor was stable at $101 \mathrm{kPa}$ (atmospheric pressure) and B. methylotrophicum achieved a maximum consumption rate of $20 \mathrm{~mL}$ syngas/h by exerting enough suction to pull Syngas A from the sampling bag.

During the first $175 \mathrm{~h}$ of process time, five series of sequential syngas batches were performed. After the second sequential syngas feed, from $120 \mathrm{~h}$ onwards, the pressure decreased rapidly with each replenishment of the bioreactor gas phase. The rate of syngas consumption increased more than 3.2 times from the period of $120-150 \mathrm{~h}$ to $150-168 \mathrm{~h}$ and $168-175 \mathrm{~h}$, corresponding to a pressure decrease of $0.67,2.1$ and $2.3 \mathrm{kPa} / \mathrm{h}$, respectively. The acceleration of syngas bioconversion rate after the initial adaptation to Syngas A was accompanied by an increase in cell density, indicating an effective growth of $B$. methylotrophicum that was maintained until $288 \mathrm{~h}$ under batch or on-demand syngas infeed (Figure 2).

At $\mathrm{pH} 7.0$ the cells needed a small adaptation period after which they were able to keep a constant consumption of syngas and produce both biomass and organic acids. The bioconversion of syngas to acetate and butyrate followed a similar trend to that of cell 
growth. The acetate and butyrate concentrations reached 38.3 and $2.0 \mathrm{mM}$, respectively, corresponding to the conversion of $83 \mathrm{~mol} \%$ of the total carbon provided by the syngas, in contrast with $61 \mathrm{~mol} \%$ obtained in the shake flask assay at $\mathrm{pH}$ 7.0. During the operation period at $\mathrm{pH} 6.0,79 \mathrm{~mol} \%$ of the carbon provided on syngas was converted to biomass, and organic acids and the acetate and butyrate production reached $55.6 \mathrm{mM}$ and $1.3 \mathrm{mM}$, respectively.

Comparing the growth at $\mathrm{pH} 7.0$ in the serum flasks and in the bioreactor, it was possible to observe that the lag phase was significantly higher in the bioreactor, most likely associated with mass transfer limitations in a larger liquid volume. Lower gas solubility and transport through the liquid medium to the surface of cells impacted not only on B. methylotrophicum growth, but also on acids production in the first $120 \mathrm{~h}$. After this adaptation period, the cells were able to grow and produce acetate at a maximum of $0.2 \mathrm{mM} / \mathrm{h}$ from 145 to $288 \mathrm{~h}$, while also producing butyrate from $145 \mathrm{~h}$ onward. Just before the $\mathrm{pH}$ setpoint was changed to 6.0, the complete consumption of $\mathrm{CO}$ and $\mathrm{H}_{2}$ and a decrease of $\mathrm{CO}_{2}$ to $8.7 \%(v / v)$ were registered in the bioreactor.

The acidification of the culture medium to $\mathrm{pH} 6.0$ resulted in a rapid decay of the cell density inside the bioreactor (Figure 2). On the contrary, the metabolic activity of $B$. methylotrophicum was maintained, as observed by the sharp decrease of the internal pressure when the syngas feed was changed to batch mode (336-389 h). In the first hours at $\mathrm{pH} 6.0$, the syngas conversion rates were not correlated with $B$. methylotrophicum growth, but with acid production. After $26 \mathrm{~h}$ at $\mathrm{pH} 6.0$ the cells maintained a syngas consumption rate of $20 \mathrm{~mL} / \mathrm{h}$ and acetate production. After this period, acetate production ceased, and the concentration of butyrate decreased (Figure 2). Duncan et al., 2002 described the ability that some gut microorganisms from the Roseburia, Coprococcus and Faecalibacterium genera have to reassimilate both acetic and butyric acids to acetyl-CoA as a way to replenish membrane and phosphorylation potentials [45]. This may be a response to the acidic conditions in the culture medium, because after $167 \mathrm{~h}$ at $\mathrm{pH} 6.0$ the cells restarted to produce acids, namely, $13.6 \mathrm{mM}$ acetate and $1.6 \mathrm{mM}$ butyrate, until the end of the experiment.

In this work, promising values of carbon fixation were obtained. To maximize the dissolution of the syngas in the culture medium, the common process employed in the literature is to force a high inflow of syngas into the bioreactor $[8,16,25,46]$. However, as the syngas inflow is higher than the microbial syngas conversion rate, most of the gas leaving the bioreactor still contains a significant percentage of carbon $[8,28,33]$. The ondemand syngas feed enabled $B$. methylotrophicum to fully access the available carbon before pulling fresh syngas from the gas bag, resulting in the full consumption of both $\mathrm{CO}$ and $\mathrm{H}_{2}$, whereas the consumption of the remaining $\mathrm{CO}_{2}$ was only limited by the available $\mathrm{H}_{2}$.

\subsection{Long-Term Lignin Syngas Bioconversion by B. methylotrophicum}

The bioreactor operation started with the culture of B. methylotrophicum in Syngas A for biomass formation. After the initial period of approximately $60 \mathrm{~h}$, the syngas feed was changed to Syngas B and the fermentation continued for more $380 \mathrm{~h}$. During the $380 \mathrm{~h}$ of bioreactor operation with Syngas B, half the volume of the liquid fermentate medium was replaced by new nutrient stock solution when the syngas consumption rate started to decrease. The first replacement occurred immediately after switching from Syngas A to Syngas B feed, and the second and third replacements occurred at 112 and $176 \mathrm{~h}$, respectively (as indicated by the red dashed lines in Figure 3). Between 0 and $232 \mathrm{~h}$ the $\mathrm{pH}$ set-point was adjusted to 7.0, whereas from 232 to $380 \mathrm{~h}$ the $\mathrm{pH}$ was changed to 6.0 simultaneously with the supplementation of the culture medium with $60 \mathrm{mM}$ sodium acetate $(\mathrm{NaAc})$, as indicated by the red dashed line at $232 \mathrm{~h}$.

The chosen feeding mode for Syngas B was the on-demand supply. The gas was introduced into the bioreactor from a $20 \mathrm{~L}$ gas sampling bag that was filled with syngas directly from the BFB gasifier and was connected with the bioreactor through a flowmeter.

Figure 3, and Tables 4 and 5, show the results obtained in this assay. 

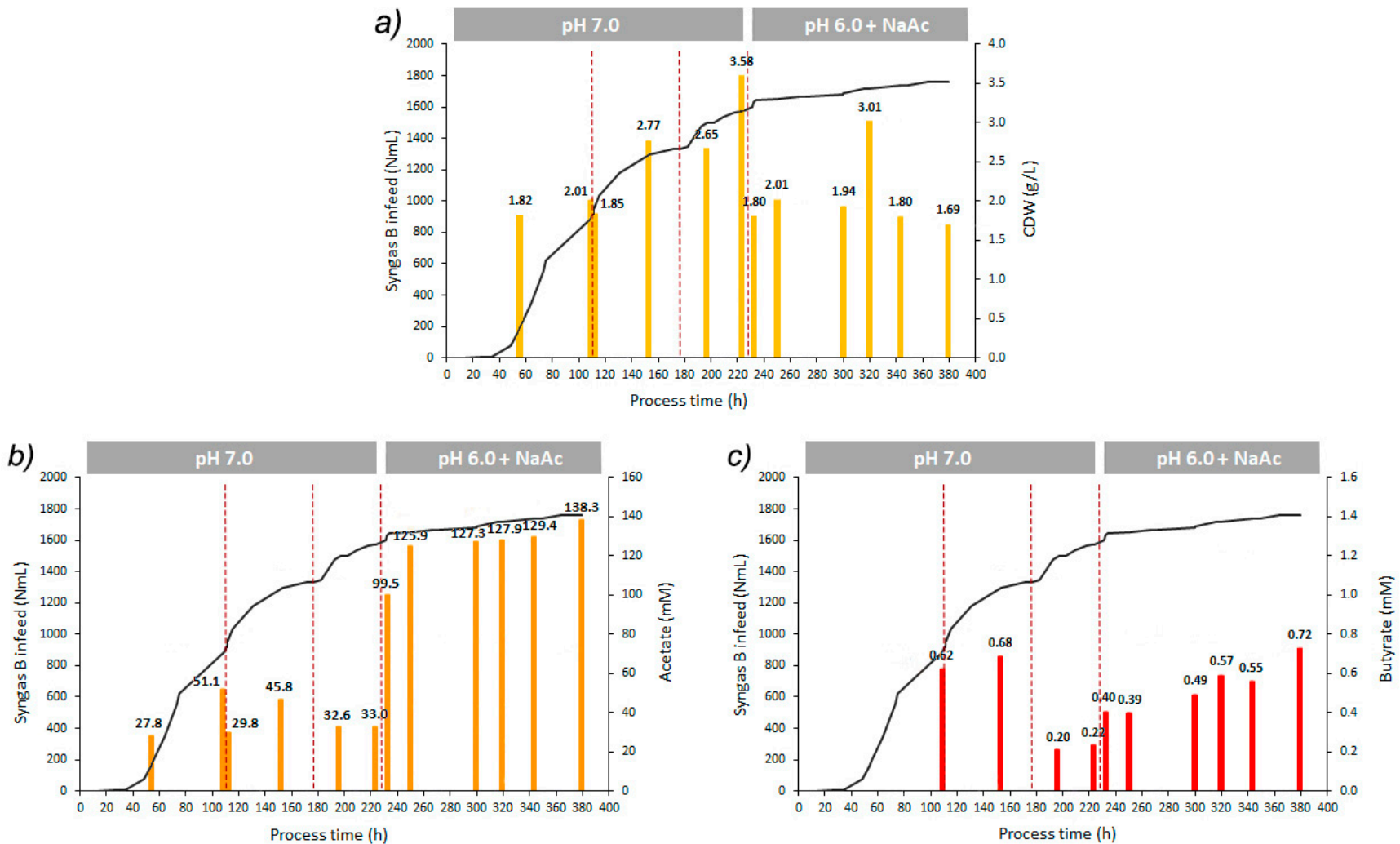

Figure 3. Time course representation of B. methylotrophicum growth with on-demand Syngas B supply at pH 7.0 and 6.0. The continuous line represents the volume of Syngas B infeed, and the colored vertical bars represent (a) cell dry weight $(\mathrm{CDW}),(\mathbf{b})$ acetate concentration and (c) butyrate concentration. The vertical dashed lines represent the time points where the culture medium was partially replaced by new nutrient stock solution during $\mathrm{pH} 7.0$ or when the pH set-point was changed to 6.0 and the culture medium was supplemented with sodium acetate.

Table 4. Syngas feed, cell growth, yields and productivities achieved in the bioconversion of Syngas B by B. methylotrophicum in four sequential batches under on-demand gas feed, at $\mathrm{pH} 7.0$ and $\mathrm{pH} 6.0$.

\begin{tabular}{|c|c|c|}
\hline Parameters & $\mathrm{pH} 7.0$ & pH 6.0; NaAc Supplementation \\
\hline Time period (h) & $0-232$ & $232-380$ \\
\hline \multirow[t]{2}{*}{$\mathrm{V}_{\text {syngas }}(\mathrm{NmL})$} & 1600 & 157 \\
\hline & $13.3^{\dagger}$ & \\
\hline \multirow[t]{2}{*}{$\mathrm{r}_{\mathrm{Smax}}(\mathrm{NmL} / \mathrm{h})$} & $6.7 \ddagger$ & 0.9 \\
\hline & $3.2 *$ & \\
\hline $\mathrm{OD}_{(600 \mathrm{~nm}) \max }$ & 1.71 & 0.65 \\
\hline \multirow{2}{*}{ CDW (g/L) } & $2.77^{1}$ & 3012 \\
\hline & $3.58^{2}$ & $3.01^{2}$ \\
\hline Max. acetate produced (mM) & 51.1 & 38.9 \\
\hline \multirow[t]{2}{*}{ Max. acetate concentration (mM) } & 51.1 & 138.3 \\
\hline & $1.20 \times 10^{-2+}$ & \\
\hline \multirow[t]{2}{*}{$\mathrm{Y}_{\mathrm{P} / \mathrm{S}}$ acetate $\left(\mathrm{mmol} / \mathrm{L}_{\text {syngas used }}\right)$} & $2.42 \times 10^{-2 \ddagger}$ & $1.24 \times 10^{-1}$ \\
\hline & $2.16 \times 10^{-3 *}$ & \\
\hline Max. butyrate produced (mM) & 0.7 & 0.3 \\
\hline \multirow[t]{2}{*}{ Max. butyrate concentration (mM) } & 0.7 & 0.7 \\
\hline & $3.29 \times 10^{-4 \dagger}$ & \\
\hline \multirow[t]{2}{*}{$\mathrm{Y}_{\mathrm{P} / \mathrm{S}}$ butyrate $\left(\mathrm{mmol} / \mathrm{L}_{\text {syngas used }}\right)$} & $1.03 \times 10^{-3 \ddagger}$ & $1.26 \times 10^{-3}$ \\
\hline & $1.02 \times 10^{-4 *}$ & \\
\hline
\end{tabular}

$\mathrm{r}_{\mathrm{S} \text { max }}$, maximum volumetric rate of syngas consumption; $\mathrm{Y}_{\mathrm{P} / \mathrm{S}}$, product yield (maximum acid produced in terms of total syngas used); ${ }^{1}$, no cell aggregation was observed; ${ }^{2}$, cell aggregation occurred; ${ }^{\dagger}$, determined in the 1 st batch; ${ }^{\ddagger}$, determined in the 2 nd batch; ${ }^{*}$, determined in the 3rd batch. 
Table 5. $\mathrm{CO}, \mathrm{CO}_{2}$ and $\mathrm{H}_{2}$ consumption and carbon fixation during the bioconversion of Syngas $\mathrm{B}$ by B. methylotrophicum.

\begin{tabular}{ccc}
\hline Parameters & pH 7.0 & pH 6.0; NaAc Supplementation \\
\hline Time period $(\mathrm{h})$ & $0-64$ & $234-299$ \\
CO consumed $(\mathrm{mmol})$ & 14.4 & 0.4 \\
$\mathrm{CO}_{2}$ negative balance $(\mathrm{mmol})$ & 7.1 & 1.9 \\
$\mathrm{H}_{2}$ consumed $(\mathrm{mmol})$ & 11.2 & - \\
$\mathrm{r}_{\mathrm{CO}}(\mathrm{mmol} / \mathrm{h})$ & 0.23 & 0.01 \\
$\mathrm{r}_{\mathrm{CO}}(\mathrm{mmol} / \mathrm{h})$ & 0.11 & 0.03 \\
$\mathrm{r}_{\mathrm{H}_{2}}(\mathrm{mmol} / \mathrm{h})$ & 0.18 & - \\
$\mathrm{CF}_{\text {, total }}(\mathrm{mol} \%)$ & 88 & 48 \\
$\mathrm{CF}$, partial $(\mathrm{mol} \%)$ & $\mathrm{CO}: 100$ & $\mathrm{CO}: 93$ \\
& $\mathrm{CO}_{2}: 71$ & $\mathrm{CO}_{2}: 43$ \\
\hline
\end{tabular}

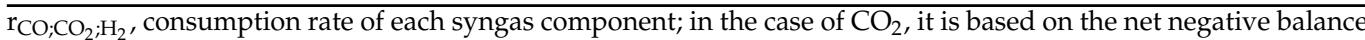
between $\mathrm{CO}_{2}$ consumption and $\mathrm{CO}_{2}$ production; $\mathrm{CF}$, total, total carbon fixation calculated using Equation (1); $\mathrm{CF}$ partial $\mathrm{CO}, \mathrm{CO}$ fixation calculated using Equation (1); $\mathrm{CF}$ partial $\mathrm{CO}_{2}, \mathrm{CO}_{2}$ fixation calculated using Equation (1).

A total of $1757 \mathrm{~mL}$ of Syngas B were fed on-demand to the bioreactor, from which $1600 \mathrm{~mL}$ were consumed by B. methylotrophicum when the $\mathrm{pH}$ set-point was 7.0. A small lag phase of $35 \mathrm{~h}$ was visible at the beginning of the assay, after which syngas consumption by B. methylotrophicum increased continuously during the process time. However, throughout the period at $\mathrm{pH} 7.0$, the Syngas B inflow rate decreased during the three consecutive substitutions of nutrient solution, from 13.3 to 6.7 and $3.2 \mathrm{NmL} / \mathrm{h}$ (Figure 3). A maximum of $51.1 \mathrm{mM}$ acetate and $0.7 \mathrm{mM}$ butyrate were produced at $\mathrm{pH}$ 7.0. The concentration of organic acids in the culture medium decreased after each medium renovation down to $33.0 \mathrm{mM}$ acetate and $0.2 \mathrm{mM}$ butyrate after the 2 nd replacement.

At $\mathrm{pH} 6.0$ the slope of Syngas B consumption was clearly less pronounced and only $157 \mathrm{~mL}$ were consumed by B. methylotrophicum during the remaining $148 \mathrm{~h}$ (Figure 3). Immediately after changing the $\mathrm{pH}$ set-point, the trend for syngas demand decreased, indicating some stress to the cells. At this $\mathrm{pH}, 38.9 \mathrm{mM}$ of acetate was further produced, corresponding to a product yield of $1.24 \times 10^{-1} \mathrm{mmol} / \mathrm{L}_{\text {syngas used }}$. The concentration of butyrate increased steadily at $\mathrm{pH} 6.0$ and the maximum concentration amounted to $0.7 \mathrm{mM}$, with a product yield of $1.26 \times 10^{-3} \mathrm{mmol} / \mathrm{L}_{\text {syngas used }}$.

During the sequential batches at $\mathrm{pH} 7.0$, the culture medium in the bioreactor started to acquire a grey color (Figure 4), possibly associated with the presence of some tar compounds and other impurities in Syngas B. Cells also started to form aggregates that hindered optical density measurements. This behavior is common in stressed cells, as a mechanism of defense against chemical contaminants in the culture medium [47]. Even so, B. methylotrophicum cells were able to produce both acetate $(51.1 \mathrm{mM})$ and butyrate $(0.7 \mathrm{mM})$ although at lower concentrations than from synthetic syngas. After the acidification of the culture medium to $\mathrm{pH} 6.0$ and acetate supplementation, the cellular growth rate decreased even further. High amounts of impurities started to deposit in the bioreactor, and the culture medium became completely dark (Figure 4c). Organic acid production proceeded, yielding further $38.8 \mathrm{mM}$ acetate and $0.3 \mathrm{mM}$ butyrate. The abrupt decrease in syngas consumption from $\mathrm{pH} 7.0$ to $\mathrm{pH} 6.0$ further supports the theory that the cells were already highly stressed and metabolically affected by the conditions in the culture medium. It has been reported that crude syngas may contain several impurities that are potentially inhibitory to microorganisms, e.g., cyanide compounds, which can impact microbial growth and syngas bioconversion performance $[9,11,12,17]$. 


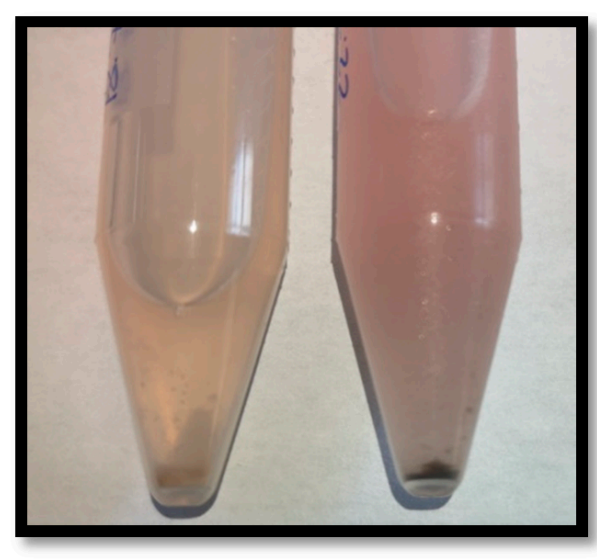

(a)

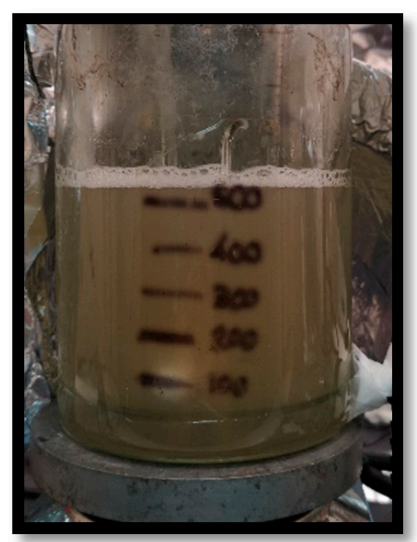

(b)

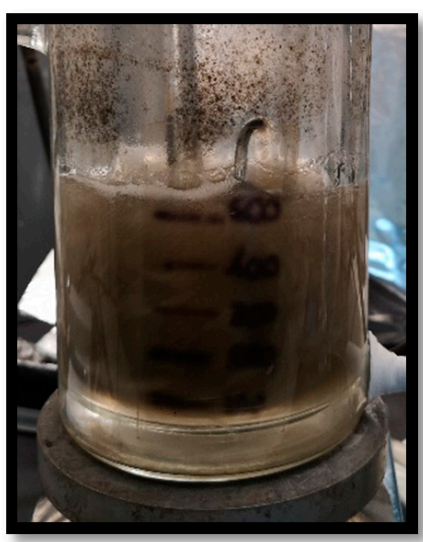

(c)

Figure 4. (a) Cells collected from the bioreactor at the beginning of Syngas B bioconversion by B. methylotrophicum (left) and at the end of the three $\mathrm{pH} 7.0$ batch series (right); (b) culture media in the bioreactor at the end of the Syngas A bioconversion; (c) culture media in the bioreactor at the end of Syngas B bioconversion.

Since headspace sampling would highly influence the batch culture due to forced entry of fresh syngas, only four gaseous samples were collected from the bioreactor during the whole experiment, to monitor the gas composition in a time period of $64 \mathrm{~h}$ at $\mathrm{pH} 7.0$ and $65 \mathrm{~h}$ at $\mathrm{pH}$ 6.0. Table 5 shows the results of carbon and $\mathrm{H}_{2}$ conversion by the cells in these time periods.

During the first $64 \mathrm{~h}$ of growth, B. methylotrophicum was able to convert a total of $21.5 \mathrm{mmol}$ of $\mathrm{CO}+\mathrm{CO}_{2}$ to products and biomass, corresponding to a total carbon fixation of $88 \mathrm{~mol} \%$. CO was the preferential carbon source, with a conversion of $100 \mathrm{~mol} \%$ at $\mathrm{pH}$ 7.0, whereas $\mathrm{CO}_{2}$ registered a negative balance of only $71 \mathrm{~mol} \%$. At pH 6.0 only $2.3 \mathrm{mmol}$ of carbon was converted (approximately 10 times less), with a total carbon fixation of $48 \mathrm{~mol} \%$. Even though CO was still the preferential carbon source ( $93 \mathrm{~mol} \%$ fixation), its conversion rate was significantly lower $(0.01 \mathrm{mmol} / \mathrm{h})$. Regarding $\mathrm{CO}_{2}$, only $43 \mathrm{~mol} \%$ was converted at a rate of $0.03 \mathrm{mmol} / \mathrm{h}$.

The carbon fixation obtained with Syngas B at pH 7.0 was similar to that obtained with Syngas A. Comparatively, a carbon fixation value of $55.9 \mathrm{~mol} \%$ was obtained in the conversion of lignin syngas with a composition similar to that of Syngas B by Clostridium ljungdahlii, with a constant inflow into the bioreactor [8]. Comparing the two forms of gas feed, the constant inflow results in higher carbon conversion rates, whereas the on-demand feed used in the present work resulted in higher carbon fixation.

As the bioconversion process proceeded, the stress to which the cells were exposed caused a drastic decrease in syngas consumption, halving the value obtained at the beginning of the assay (from 20 to $13 \mathrm{~mL} / \mathrm{h}$ ). Infantes et al., 2020 [8] observed the same effect during lignin syngas bioconversion by $C$. ljungdahlii, where syngas impurities highly influenced both productivity and carbon fixation. In the present study, the cumulative inhibitory effects caused by the prolonged exposure to Syngas $\mathrm{B}$, the $\mathrm{pH}$ adjustment to 6.0 , and the acetate surplus in the culture medium led to an accumulation of cell stress that influenced negatively, and decisively, the bioconversion performance of B. methylotrophicum. Additional research, namely the selection of more robust and adapted strains and the implementation of additional syngas cleaning steps, is needed to overcome the problems described.

A tentative carbon balance was undertaken based on the lignin A composition and additional data from the literature $[3,48]$. The results are preliminary and limited by the small number of gas samples collected from the bioreactor headspace, at 0, 64, 234 and $299 \mathrm{~h}$ of process time (Table 5). Figure 5 represents the process schematic with the corresponding inputs and outputs. 


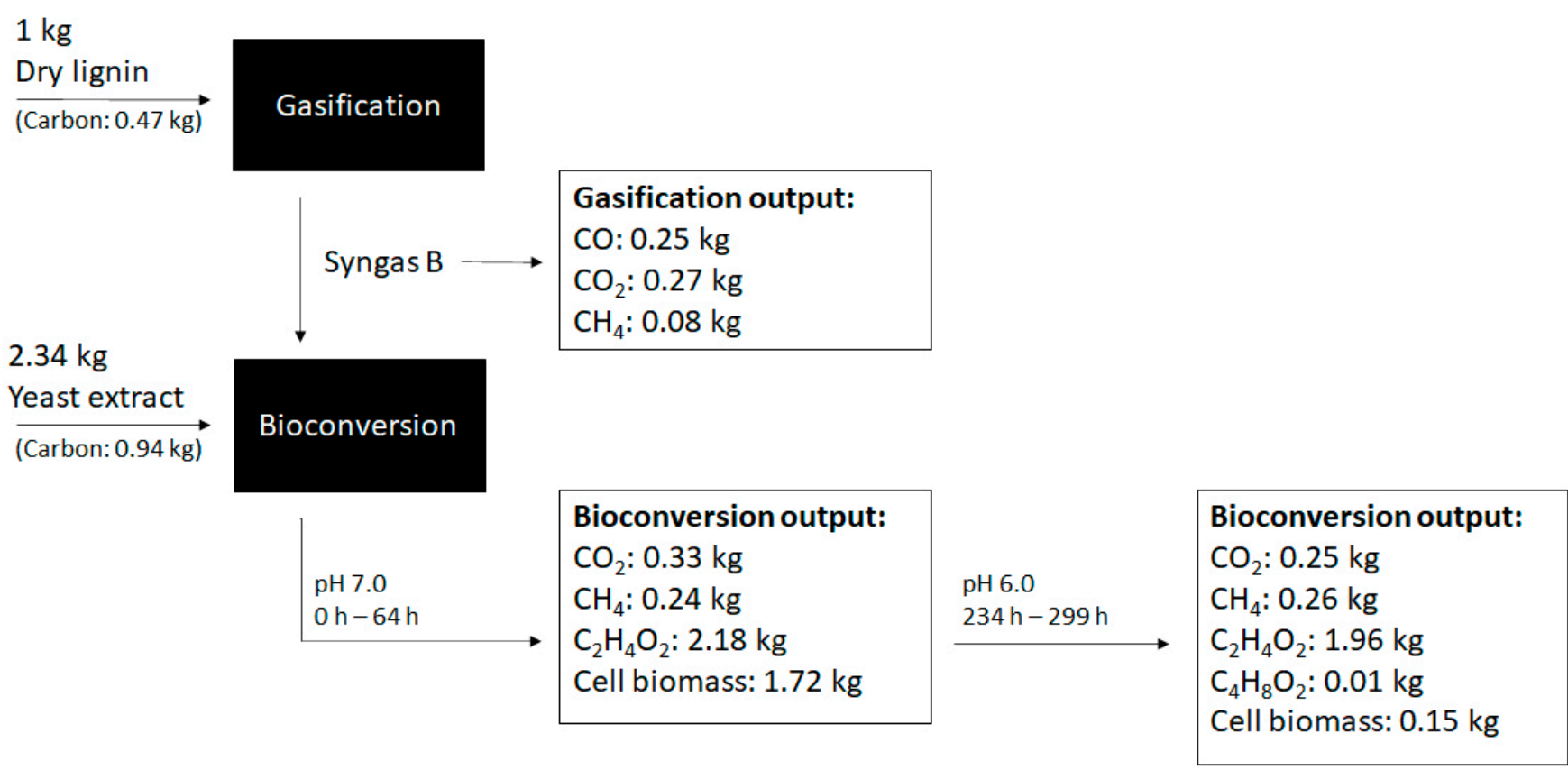

Figure 5. Process schematic of Syngas B production and bioconversion, representing the carbon inputs and outputs per kg of dry lignin.

Using the BFB gasification yield of $900 \mathrm{~L}$ of Syngas B produced from $1 \mathrm{~kg}$ of dry lignin determined by Liakakou et al., $2019,0.25 \mathrm{~kg}$ of $\mathrm{CO}, 0.27 \mathrm{~kg}$ of $\mathrm{CO}_{2}, 0.08 \mathrm{~kg}$ of $\mathrm{CH}_{4}$, and residual concentrations of hydrocarbons and tars were obtained [3]. The bioconversion of Syngas B by B. methylotrophicum at pH 7.0 resulted in the accumulation of $0.33 \mathrm{~kg}$ of $\mathrm{CO}_{2}$ and $0.24 \mathrm{~kg}$ of $\mathrm{CH}_{4}$ in the headspace gas, and in the production of $2.18 \mathrm{~kg}$ of acetic acid and $1.72 \mathrm{~kg}$ of cell biomass per $\mathrm{kg}$ of lignin. All the available $\mathrm{CO}$ was converted to products and biomass simultaneously with a slight accumulation of $\mathrm{CO}_{2}$ and a significant accumulation of $\mathrm{CH}_{4}$ in the bioreactor headspace. At $\mathrm{pH} 6.0,0.25 \mathrm{~kg}$ of $\mathrm{CO}_{2}$ and $0.26 \mathrm{~kg}$ of $\mathrm{CH}_{4}$ were accumulated, whereas $1.96 \mathrm{~kg}$ of acetic acid, $0.01 \mathrm{~kg}$ of butyrate and $0.15 \mathrm{~kg}$ of biomass were produced. The switch to more acidic conditions placed the cells under extreme stress, but they were still able to metabolize the $\mathrm{CO}$ to acids.

Under the tested conditions, the gasification to Syngas $\mathrm{B}$ without subsequent bioconversion would release $0.49 \mathrm{~kg}$ of carbon in the form of $\mathrm{CO}, \mathrm{CO}_{2}$ and $\mathrm{CH}_{4}$ per $\mathrm{kg}$ of dry lignin. Conversely, the bioconversion of Syngas B would result in the direct fixation of approximately $73 \%$ of the carbon of the gasification output. This value can be further increased through optimization of the overall process, for example, with the supply of additional $\mathrm{H}_{2}$ to increase $\mathrm{CO}_{2}$ conversion, the removal of easily accessible carbon sources, such as yeast extract, in the culture medium, and the adoption of a continuous culture setting. This latter modification would alleviate the inhibitory effect of crude syngas on the cells by reducing the accumulation of impurities inside the bioreactor. The broad carbon fixation potential of this bio-thermochemical based technology ranges from the conversion of syngas produced by the gasification of organic waste materials, such as low-grade technical lignin, biomass residues and municipal solid waste, to the use of gaseous carbon substrates, such as industrial waste gases. Raw material flexibility is extremely aligned with ambitious, yet urgent, climate change adaptation strategies. This will shape the decarbonization of the economy, orienting the circular action plans towards more sustainable products and technologies for the incorporation and capture of $\mathrm{CO}_{2}[49,50]$. In future prospects, a techno economic analysis (TEA) and life cycle analysis (LCA) of this process with generated fermentation metrics will be important in order to prove the viability of the proposed biomass-to-chemicals integrated biorefinery. Moreover, it will allow the identification of possible process improvement alternatives at an early development stage. Although LCA studies exist in the literature for volatile fatty acids, for TEA, to the best of 
the authors' knowledge, is still scarce, which enforces the need of such combined studies for this integrated biorefinery.

\section{Conclusions}

This work highlighted the potential of B. methylotrophicum to be used in crude syngas fermentation, converting $\mathrm{CO}$ - and $\mathrm{CO}_{2}$-rich gas streams into platform carboxylic acids. The values of carbon fixation from synthetic syngas (Syngas A) by this acetogen reached $88 \mathrm{~mol} \%$ of the supplied carbon in small scale experiments and $83 \mathrm{~mol} \%$ in a long-term operated bioreactor. B. methylotrophicum also demonstrated the ability to consume lignin syngas (Syngas B) and was able to use $88 \mathrm{~mol} \%$ of the supplied carbon, with fixation of $71 \mathrm{~mol} \%$ of the available $\mathrm{CO}_{2}$ and complete fixation of the $\mathrm{CO}$ at $\mathrm{pH}$ 7.0. In smallscale experiments with synthetic syngas, the maximum acetate production was $32.0 \mathrm{mM}$ at $\mathrm{pH} 6.0$, whereas in the bioreactor the production reached $38.3 \mathrm{mM}$ at $\mathrm{pH} 7.0$. The supplementation of the culture medium with sodium acetate supported a 6.3-fold increase in butyrate production under more acidic conditions. This effect was less clear in the bioreactor assay, with a maximum butyrate production of $1.2 \mathrm{mM}$ at $\mathrm{pH}$ 6.0. Nevertheless, an increase of more than two-fold in the butyrate per acetate produced ratio was observed in this condition.

There was a clear influence of $\mathrm{pH}$ on the production profile of B. methylotrophicum from Syngas A, with lower $\mathrm{pH}$ and excess acetate shifting metabolism towards butyrate production. When using lignin-derived Syngas B this effect was not as evident, most likely due to the accumulation of toxic syngas impurities inside the bioreactor that acted as additional stress factors to the cells. At $\mathrm{pH}$ 6.0, acetate and butyrate production were residual for $148 \mathrm{~h}$, Syngas B consumption rate by B. methylotrophicum decreased drastically to $0.9 \mathrm{NmL} / \mathrm{h}$, and cell density dropped significantly to an O.D.600nm of 0.65 . These results seem to indicate that a future syngas-based biorefinery would benefit from a modified bioreactor system, possibly with continuous cell renewal, to reduce the influence of inhibitors present in the crude syngas. More work on strain adaption to syngas impurities is required, since $B$. methylotrophicum demonstrated some initial resilience to the exposure to crude syngas. Ultimately this work demonstrated the importance of testing the bioconversion of syngas not only with synthetic gas formulations, but also with real gaseous waste streams, to correctly predict cell behavior and limit the effect of syngas impurities.

Author Contributions: Conceptualization, P.M. and M.P.; Methodology, M.P., P.M. and J.O.; validation, P.M.; formal analysis, M.P. and P.M.; investigation, M.P. and J.O.; resources, F.P.; writingoriginal draft preparation, M.P. and P.M.; writing-review and editing, P.M., C.S., J.O., F.P. and F.G.; supervision, P.M. and C.S.; project administration, F.G.; funding acquisition, F.G. and P.M. All authors have read and agreed to the published version of the manuscript.

Funding: This research was performed under the framework of the AMBITION Project, an ECRIA project funded by the European Union's Horizon 2020 research and innovation program, under grant agreement No. 731263, and the Operational Program for Competitiveness and Internationalization (PORTUGAL 2020), Lisbon Portugal Regional Operational Program (Lisboa 2020) and North Portugal Regional Operational Program (Norte 2020) under the Portugal 2020 Partnership Agreement, through the European Regional Development Fund (ERDF). MP and JO were supported by FCT through PhD grants DFA/BD/6423/2020 and SFRH/BD/107780/2015, respectively. The authors would like to acknowledge FCT through project UIDB/50019/2021-Instituto Dom Luiz.

Institutional Review Board Statement: Not applicable.

Informed Consent Statement: Not applicable.

Data Availability Statement: Not applicable.

Acknowledgments: The authors would like to thank Tania Chen Barbachano for proofreading and editing the present manuscript. The authors would also like to thank the technical assistance of Luís Ramalho (GC analysis).

Conflicts of Interest: The authors declare no conflict of interest. 


\section{References}

1. Parisi, C. Distribution of the Bio-Based Industry in the EU; Publications Office of the European Union: Luxembourg, 2020. [CrossRef]

2. Wen, J.-L.; Wang, H.-M.; Ma, C.-Y.; Yuan, T.-Q.; Sun, R.-C. Value-added products from lignin: Isolation, characterization and applications. In Biomass, Biofuels, Biochemicals: Lignin Biorefinery; Bhaskar, T., Pandey, A., Eds.; Elsevier: Amsterdam, The Netherlands, 2021; pp. 33-55. ISBN 9780128202944.

3. Liakakou, E.T.; Vreugdenhil, B.J.; Cerone, N.; Zimbardi, F.; Pinto, F.; André, R.; Marques, P.; Mata, R.; Girio, F. Gasification of Lignin-Rich Residues for the Production of Biofuels via Syngas Fermentation: Comparison of Gasification Technologies. Fuel 2019, 251, 580-592. [CrossRef]

4. Whitty, K.J.; Zhang, H.R.; Eddings, E.G. Emissions from Syngas Combustion. Combust. Sci. Technol. 2008, 180, 1117-1136. [CrossRef]

5. Henstra, A.M.; Sipma, J.; Rinzema, A.; Stams, A.J. Microbiology of Synthesis Gas Fermentation for Biofuel Production. Curr. Opin. Biotechnol. 2007, 18, 200-206. [CrossRef] [PubMed]

6. Kumar, S.; Muthu Dineshkumar, R.; Angkayarkan Vinayakaselvi, M.; Ramanathan, A. Bio-Ethanol Production from SyngasDerived Biomass: A Review. Mater. Today Proc. 2021, 46, 9989-9993. [CrossRef]

7. Pinto, F.; André, R.; Marques, P.; Mata, R.; Pacheco, M.; Moura, P.; Gírio, F. Production of Syngas Suitable to Be Used in Fermentation to Obtain Biochemical Added-Value Compounds. Chem. Eng. Trans. 2019, 76, 1399-1404. [CrossRef]

8. Liakakou, E.T.; Infantes, A.; Neumann, A.; Vreugdenhil, B.J. Connecting Gasification with Syngas Fermentation: Comparison of the Performance of Lignin and Beech Wood. Fuel 2021, 290, 120054. [CrossRef]

9. Infantes, A.; Kugel, M.; Raffelt, K.; Neumann, A. Side-by-side Comparison of Clean and Biomass-Derived, Impurity-containing Syngas as Substrate for Acetogenic Fermentation with Clostridium ljungdahlii. Fermentation 2020, 6, 84. [CrossRef]

10. Ramachandriya, K.D.; Wilkins, M.R.; Patil, K.N. Influence of Switchgrass Generated Producer Gas Pre-Adaptation on Growth and Product Distribution of Clostridium ragsdalei. Biotechnol. Bioprocess Eng. 2013, 18, 1201-1209. [CrossRef]

11. Xu, D.; Lewis, R.S. Syngas Fermentation to Biofuels: Effects of Ammonia Impurity in Raw Syngas on Hydrogenase Activity. Biomass Bioenergy 2012, 45, 303-310. [CrossRef]

12. Xu, D.; Tree, D.R.; Lewis, R.S. The Effects of Syngas Impurities on Syngas Fermentation to Liquid Fuels. Biomass Bioenergy 2011, 35, 2690-2696. [CrossRef]

13. Ahmed, A.; Lewis, R.S. Fermentation of Biomass-Generated Synthesis Gas: Effects of Nitric Oxide. Biotechnol. Bioeng. 2007, 97, 1080-1086. [CrossRef] [PubMed]

14. Datar, R.P.; Shenkman, R.M.; Cateni, B.G.; Huhnke, R.L.; Lewis, R.S. Fermentation of Biomass-Generated Producer Gas to Ethanol. Biotechnol. Bioeng. 2004, 86, 587-594. [CrossRef] [PubMed]

15. Ahmed, A.; Cateni, B.G.; Huhnke, R.L.; Lewis, R.S. Effects of Biomass-Generated Producer Gas Constituents on Cell Growth, Product Distribution and Hydrogenase Activity of Clostridium carboxidivorans P7 ${ }^{\mathrm{T}}$. Biomass Bioenergy 2006, 30, 665-672. [CrossRef]

16. Kundiyana, D.K.; Huhnke, R.L.; Wilkins, M.R. Syngas Fermentation in a 100-L Pilot Scale Fermentor: Design and Process Considerations. J. Biosci. Bioeng. 2010, 109, 492-498. [CrossRef] [PubMed]

17. Oswald, F.; Zwick, M.; Omar, O.; Hotz, E.N.; Neumann, A. Growth and Product Formation of Clostridium ljungdahlii in Presence of Cyanide. Front. Microbiol. 2018, 9. [CrossRef] [PubMed]

18. Zeikus, J.G.; Lynd, L.H.; Thompson, T.E.; Krzycki, J.A.; Weimer, P.J.; Hegge, P.W. Isolation and Characterization of a New, Methylotrophic, Acidogenic Anaerobe, the Marburg Strain. Curr. Microbiol. 1980, 3, 381-386. [CrossRef]

19. Bertsch, J.; Müller, V. Bioenergetic Constraints for Conversion of Syngas to Biofuels in Acetogenic Bacteria. Biotechnol. Biofuels 2015, 8, 210. [CrossRef] [PubMed]

20. Kennes, D.; Abubackar, H.N.; Diaz, M.; Veiga, M.C.; Kennes, C. Bioethanol Production from Biomass: Carbohydrate vs Syngas Fermentation. J. Chem. Technol. Biotechnol. 2016, 91, 304-317. [CrossRef]

21. Deshmukh, G.; Manyar, H. Production Pathways of Acetic Acid and Its Versatile Applications in the Food Industry. In Acetic Acid-Production and Applications in the Food Industry [Working Title]; IntechOpen: London, UK, 2020; ISBN 978-1-83881-182-2.

22. Xu, Z.; Jiang, L. Butyric Acid. In Comprehensive Biotechnology; Moo-Young, M., Ed.; Pergamon: Elmsford, NY, USA, 2011; Volume 3, pp. 235-243. ISBN 9780444640475.

23. Kolesinska, B.; Fraczyk, J.; Binczarski, M.; Modelska, M.; Berlowska, J.; Dziugan, P.; Antolak, H.; Kaminski, Z.J.; Witonska, I.A.; Kregiel, D. Butanol Synthesis Routes for Biofuel Production: Trends and Perspectives. Materials 2019, 12, 350. [CrossRef] [PubMed]

24. Kiefer, D.; Merkel, M.; Lilge, L.; Henkel, M.; Hausmann, R. From Acetate to Bio-Based Products: Underexploited Potential for Industrial Biotechnology. Trends. Biotechnol. 2021, 39, 397-411. [CrossRef] [PubMed]

25. Yasin, M.; Jang, N.; Lee, M.; Kang, H.; Aslam, M.; Bazmi, A.A.; Chang, I.S. Bioreactors, Gas Delivery Systems and Supporting Technologies for Microbial Synthesis Gas Conversion Process. Bioresour. Technol. Rep. 2019, 7, 100207. [CrossRef]

26. Arantes, A.L.; Moreira, J.P.C.; Diender, M.; Parshina, S.N.; Stams, A.J.M.; Alves, M.M.; Alves, J.I.; Sousa, D.Z. Enrichment of Anaerobic Syngas-Converting Communities and Isolation of a Novel Carboxydotrophic Acetobacterium wieringae Strain JM. Front. Microbiol. 2020, 11, 58. [CrossRef] [PubMed]

27. Diender, M.; Parera Olm, I.; Sousa, D.Z. Synthetic Co-Cultures: Novel Avenues for Bio-Based Processes. Curr. Opin. Biotechnol. 2021, 67, 72-79. [CrossRef] [PubMed] 
28. Oswald, F.; Dörsam, S.; Veith, N.; Zwick, M.; Neumann, A.; Ochsenreither, K.; Syldatk, C. Sequential Mixed Cultures: From Syngas to Malic Acid. Front. Microbiol. 2016, 7, 891. [CrossRef] [PubMed]

29. Gírio, F.; Marques, S.; Pinto, F.; Oliveira, A.C.; Costa, P.; Reis, A.; Moura, P. Biorefineries in the world. In Biorefineries. Lecture Notes in Energy; Rabaçal, M., Ferreira, A., Silva, C., Costa, M., Eds.; Springer: Cham, Switzerland, 2017; Volume 57, pp. 227-281. [CrossRef]

30. Worden, R.M.; Grethlein, A.J.; Zeikus, J.G.; Datta, R. Butyrate Production from Carbon Monoxide by Butyribacterium methylotrophicum. App. Biochem. Biotechnol. 1989, 20-21, 687-698. [CrossRef]

31. AOAC. Official Methods of Analysis of AOAC International, 21st ed.; Latimer, G.W., Ed.; AOAC International: Rockville, MD, USA, 2019; Volumes 1-3, ISBN 0935584897.

32. Ortigueira, J.; Alves, L.; Gouveia, L.; Moura, P. Third Generation Biohydrogen Production by Clostridium butyricum and Adapted Mixed Cultures from Scenedesmus obliquus Microalga Biomass. Fuel 2015, 153, 128-134. [CrossRef]

33. Infantes, A.; Kugel, M.; Neumann, A. Evaluation of Media Components and Process Parameters in a Sensitive and Robust Fed-Batch Syngas Fermentation System with Clostridium ljungdahlii. Fermentation 2020, 6, 61. [CrossRef]

34. Fernández-Naveira, Á.; Veiga, M.C.; Kennes, C. H-B-E (Hexanol-Butanol-Ethanol) Fermentation for the Production of Higher Alcohols from Syngas/Waste Gas. J. Chem. Technol. Biotechnol. 2017, 92, 712-731. [CrossRef]

35. Heiskanen, H.; Virkajärvi, I.; Viikari, L. The Effect of Syngas Composition on the Growth and Product Formation of Butyribacterium methylotrophicum. Enzym. Microb. Technol. 2007, 41, 362-367. [CrossRef]

36. Park, S.; Yasin, M.; Jeong, J.; Cha, M.; Kang, H.; Jang, N.; Choi, I.G.; Chang, I.S. Acetate-Assisted Increase of Butyrate Production by Eubacterium limosum KIST612 during Carbon Monoxide Fermentation. Bioresour. Technol. 2017, 245, 560-566. [CrossRef] [PubMed]

37. Diender, M.; Stams, A.J.M.; Sousa, D.Z. Production of Medium-Chain Fatty Acids and Higher Alcohols by a Synthetic Co-Culture Grown on Carbon Monoxide or Syngas. Biotechnol. Biofuels 2016, 9, 82. [CrossRef] [PubMed]

38. Drake, H.L.; Gößner, A.S.; Daniel, S.L. Old Acetogens, New Light. Ann. NY Acad. Sci. 2008, 1125, 100-128. [CrossRef] [PubMed]

39. Dürre, P. Butanol Formation from Gaseous Substrates. FEMS Microbiol. Lett. 2016, 363, 40. [CrossRef] [PubMed]

40. Richter, H.; Molitor, B.; Diender, M.; Sousa, D.Z.; Angenent, L.T. A Narrow pH Range Supports Butanol, Hexanol, and Octanol Production from Syngas in a Continuous Co-Culture of Clostridium ljungdahlii and Clostridium kluyveri with in-Line Product Extraction. Front. Microbiol. 2016, 7, 1773. [CrossRef] [PubMed]

41. Annous, B.A.; Shieh, J.-S.; Shen, G.-J.; Jain, M.K.; Zeikus, J.G. Regulation of Hydrogen Metabolism in Butyribacterium methylotrophicum by Substrate and pH. Appl. Microbiol. Biotechnol. 1996, 45, 804-810. [CrossRef]

42. Grethlein, A.J.; Worden, R.M.; Jain, M.K.; Datta, R. Continuous Production of Mixed Alcohols and Acids from Carbon Monoxide. Appl. Biochem. Biotechnol. 1990, 24, 875-884. [CrossRef]

43. Jaros, A.M.; Rova, U.; Berglund, K.A. Acetate Adaptation of Clostridia tyrobutyricum for Improved Fermentation Production of Butyrate. Springerplus 2013, 2, 47. [CrossRef] [PubMed]

44. Ueki, T.; Nevin, K.P.; Woodard, T.L.; Lovley, D.R. Converting Carbon Dioxide to Butyrate with an Engineered Strain of Clostridium ljungdahlii. mBio 2014, 5, e01636-14. [CrossRef] [PubMed]

45. Duncan, S.H.; Barcenilla, A.; Stewart, C.S.; Pryde, S.E.; Flint, H.J. Acetate Utilization and Butyryl Coenzyme A (CoA): AcetateCoA Transferase in Butyrate-Producing Bacteria from the Human Large Intestine. Appl. Environ. Microb. 2002, 68, 5186-5190. [CrossRef]

46. Fernández-Naveira, Á.; Abubackar, H.N.; Veiga, M.C.; Kennes, C. Production of Chemicals from $\mathrm{C} 1 \mathrm{Gases}(\mathrm{CO}, \mathrm{CO} 2)$ by Clostridium carboxidivorans. World J. Microbiol. Biotechnol. 2017, 33, 43. [CrossRef] [PubMed]

47. Trunk, T.; Khalil, H.S.; Leo, J.C. Bacterial Autoaggregation. AIMS Microbiol. 2018, 4, 140-164. [CrossRef] [PubMed]

48. Thompson, K.; Summers, R.; Cook, S. Development and Experimental Validation of the Composition and Treatability of a New Synthetic Bathroom Greywater (SynGrey). Environ. Sci. Water Res. Technol. 2017, 3, 1120-1131. [CrossRef]

49. Abu Hassan, M.H.; Sher, F.; Fareed, B.; Ali, U.; Zafar, A.; Bilal, M.; Iqbal, H.M.N. Sustainable Hydrates for Enhanced Carbon Dioxide Capture from an Integrated Gasification Combined Cycle in a Fixed Bed Reactor. Ind. Eng. Chem. Res. 2021, 60, 11346-11356. [CrossRef] [PubMed]

50. Ameen, M.; Zamri, N.M.; May, S.T.; Azizan, M.T.; Aqsha, A.; Sabzoi, N.; Sher, F. Effect of Acid Catalysts on Hydrothermal Carbonization of Malaysian Oil Palm Residues (Leaves, Fronds, and Shells) for Hydrochar Production. Biomass Convers. Biorefin. 2021. Available online: https:/ /link.springer.com/article/10.1007\%2Fs13399-020-01201-2 (accessed on 22 October 2021). [CrossRef] 